\title{
DIFFERENTIATING TRANSUDATIVE AND EXUDATIVE PLEURAL EFFUSION BY PLEURAL FLUID CHOLESTEROL
}

\author{
Ayyali Ambresh, Mulimani MS.
}

Department of General Medicine, BLDEU's Shri B M Patil Medical College, Vijayapura, Karnataka, India.

\begin{abstract}
Background: Pleural effusion is one of the common condition encountered in day to day practise. Pleural effusions represent a very common diagnostic task to the physician. A correct diagnosis of the underlying disease is essential to rational management. Today there are a number of laboratory tests available to differentiate exudates and transudates which are considered cost effective to the patients, so this study was designed for the measurement of pleural fluid cholesterol to differentiate transudative and exudative pleural effusions (sensitivity-97.8\%, specificity-100\%) with the advantage that a contemporary blood sample is not required, thereby lowering cost of diagnostic procedure. Objectives: To study the diagnostic value of Pleural fluid Cholesterol in differentiating transudative and exudative pleural effusions. Methodology: This cross sectional descriptive study was conducted on patients of pleural effusion ( $\mathrm{n}=60$ ) age $>18$ years patients with definitive clinical diagnosis and evidenced by radiological diagnosis of pleural effusion were taken as inclusion criteria. Results: The results showed majority of the patients were males $(63.3 \%)$ and females (36.7\%). According to lights criteria 46 patients were exudates and 14 patients were transudates and according to Pleural fluid Cholesterol criteria 45 patients were exudates and 15 patients were transudates with sensitivity of $97.8 \%$ and specificity of $100 \%$ and accuracy of $98.3 \%$.Conclusion: The pleural fluid cholesterol criteria were found to be the most efficient criteria. Since this parameter involves the measurement of only pleural fluid values of cholesterol, it has following advantages-Economically it reduces number of biochemical tests and Simpler as there is no need to take simultaneous blood sample at the time of thoracocentesis.
\end{abstract}

Keywords: Pleural Effusion; Transudates; Exudates; Cholesterol.

\section{INTRODUCTION}

Pleural effusions represent a very common diagnostic task to the physician. A correct diagnosis of the underlying disease is essential to the rational management [1].

Normally the pleural space contains only a few millimetres of fluid. Accumulation of excessive amount of fluid is a frequent manifestation of many diseases of both thoracic and extra thoracic. Indeed pleural effusion must be regarded as a trivial event but as a sign of major disorder or disease [2].

The first diagnostic step is the identification of pleural effusions as either a transudate or exudates. This is useful because it indicates the pathophysiological mechanisms involved. Exudates are secondary to alteration of capillary permeability or lymphatic drainage. Transudates are due to either alterations of hydrostatic and / or osmotic pressure in pleural capillaries or to a fluid passing from the peritoneal cavity via diaphragmatic defects.

If an exudate is present further diagnostic procedures and tests are imperative for definitive diagnosis and specific therapy. On the other hand if the fluid is clearly

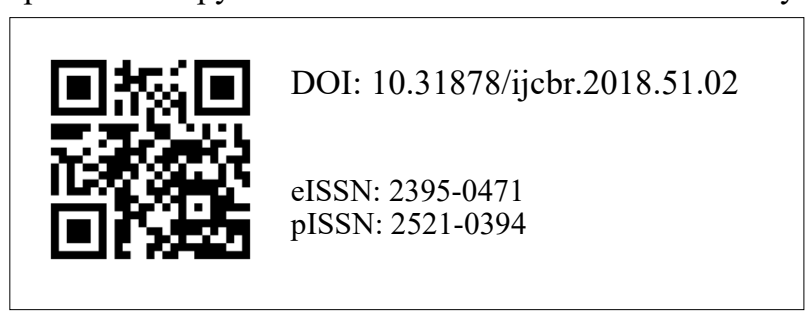

a transudate one need not worry about manoeuvres directed at the pleura and need to treat only the congestive cardiac failure, nephrosis, cirrhosis or hypoproteinemia [3].

Over the years many criteria have been developed by various workers for separation of exudates and transudates.

Objective: To study the diagnostic value of Pleural fluid Cholesterol in differentiating transudative and exudative pleural effusions.

\section{MATERIALS AND METHODS}

Study design: Cross sectional descriptive study

Ethics approval: Study was approved by the institutional ethics committee

Place of research: BLDEU'S Shri B. M. Patil medical college hospital and research centre, Vijayapura.

Study period: Period of study is from November 2016 to July 2018.

Inclusion Criteria: Data is collected from patients who are attending Medicine OPD and IPD. Age >18years, patients with definite clinical diagnosis and Pleural effusion evidenced by radiological imaging.

Exclusion criteria: Patients without definitive clinical diagnosis, and previously diagnosed or already on treatment.

Correspondence: Dr. M S Mulimani, Professor and Head, Department of General Medicine, BLDEU's Shri B M Patil Medical College, Vijayapura, Karnataka, India. E-mail: mulimanims@gmail.com

(C) Authors; 2019. International Journal of Clinical and Biomedical Research, Sumathi Publications.

This is an Open Access article which permits unrestricted non-commercial use, provided the original work is properly cited. 
Sample size: Using expected incidence of exudates cases among pleural effusion as $69.4 \%$,expected sensitivity as $88 \%$, expected specificity as $100 \%$ and desired precision as $+/-10 \%$. The minimum sample is 60 .This sample size will give the precision of $10 \%$ for both sensitivity and specificity.

\section{Formula used: $\mathrm{N}=\mathrm{z}^{2}(1-\mathrm{p}) / \mathrm{d}^{2}$}

Z-value of $\mathrm{z}$ statistic at $5 \%$ level of significance, $\mathrm{d}$ margin of error, p-expected incidence rate Methodology: Complete history of the patient and clinical signs and symptoms at presentation is collected and determined the side of effusion. Pleural fluid is aspirated and investigations like pleural fluid analsysis which includes pleural protein, pleural sugar, cell count, malignancy and pleural cholesterol is estimated. Pleural fluid cholesterol criteria is applied to differentiate transudate and exudates (pleural cholesterol $<45 \mathrm{mg} / \mathrm{dl}$ transudate and $>45 \mathrm{mg} / \mathrm{dl}$ exudates) and compared with the standard Lights criteria (pleural fluid protein: serum protein $>0.6$ )

Statistical Analysis: Data will be analysed using mean+/-SD Chi square test for association, comparison of means using test, ANOVA for comparison between and within groups and diagrammatic presentation.

\section{RESULTS}

The present study was undertaken in 60 cases of Pleural Effusion over a period of 2 and half years from November 2016 to July 2018, the results of which are given below.

Table 1. Age and sex distribution

\begin{tabular}{l|l|l|l}
\hline \multirow{2}{*}{ AGE (years) } & Male & Female & \multirow{2}{*}{ p value } \\
\cline { 2 - 3 } & N (\%) & N & \\
\hline $18-20$ & $1(2.6)$ & $0(0)$ & \\
\hline $21-30$ & $5(13.2)$ & $4(18.2)$ & \\
\hline $31-40$ & $8(21.1)$ & $7(31.8)$ & \multirow{2}{*}{0.641} \\
\hline $41-50$ & $12(31.6)$ & $3(13.6)$ & \\
\hline $51-60$ & $8(21.1)$ & $5(22.7)$ & \\
\hline$>60$ & $4(10.5)$ & $3(13.6)$ & \\
\hline Total & 38 & 22 & \\
\hline
\end{tabular}

Table 2. Distribution of symptoms in pleural effusion at presentation

\begin{tabular}{l|l}
\hline Presenting symptoms & $\begin{array}{l}\text { Number of patients } \\
(\%)\end{array}$ \\
\hline Cough & $50(83.3)$ \\
\hline Fever & $22(36.7)$ \\
\hline Chest pain & $34(56.7)$ \\
\hline Dyspnoea & $47(78.3)$ \\
\hline Swelling of limbs & $10(16.7)$ \\
\hline Distension of abdomen & $10(16.7)$ \\
\hline Facial puffiness & $6(10)$ \\
\hline Loss of appetite & $60(100)$ \\
\hline Loss of weight & $40(66.7)$ \\
\hline
\end{tabular}

Table 3. Distribution of signs in pleural effusion at presentation

\begin{tabular}{l|l}
\hline Clinical signs & N (\%) \\
\hline Stony dullness & $60(100)$ \\
\hline Absent breath sound & $50(83.3)$ \\
\hline Decreased vf/vr & $52(86.7)$ \\
\hline Mediastinal shift & $50(83.3)$ \\
\hline Pleural rub & $4(6.6)$ \\
\hline Crepitations & $5(8.3)$ \\
\hline
\end{tabular}

Table 4. Pleural effusion right and left side distribution

\begin{tabular}{l|l}
\hline Side of effusion & Number (\%) \\
\hline Right & $36(60)$ \\
\hline Left & $19(31.7)$ \\
\hline Bilateral & $5(8.3)$ \\
\hline
\end{tabular}

Out of 60 patients, 36 had right sided effusion, 19 had left sided effusion, 5 patients had bilateral pleural effusion.

Table 5. Appearance of pleural effusion

\begin{tabular}{l|l|l|l}
\hline \multirow{2}{*}{ Colour } & \multicolumn{2}{|l|}{ Total } & \multirow{2}{*}{ p value } \\
\cline { 2 - 3 } & $\mathrm{N}$ & $\%$ & \\
\hline Amber & 36 & 60.0 & \\
\hline Clear & 18 & 30.0 & \\
\hline Haemorrhagic & 4 & 6.7 & \multirow{2}{*}{0.864} \\
\hline Straw & 2 & 3.3 & \\
\hline Total & 60 & 100.0 & \\
\hline
\end{tabular}

Colour of pleural effusion - 36 patients had amber colour, 18 patients had clear, 4 patients had haemorrhagic and straw colour in 2 patients.

Table 6. Cytology of pleural effusion

\begin{tabular}{l|l|l}
\hline \multirow{2}{*}{ Cytology } & Total & \multirow{2}{*}{ p value } \\
\cline { 2 - 2 } & $\mathrm{N}$ & \\
\hline $\begin{array}{l}\text { Lymphocytes + Mesotheli- } \\
\text { al cells }\end{array}$ & $3(5)$ & \\
\hline $\begin{array}{l}\text { Predominantly lympho- } \\
\text { cytes }\end{array}$ & $42(70)$ & \multirow{2}{*}{0.476} \\
\hline Predominantly neutrophils & $15(25)$ & \\
\hline Total & 60 & \\
\hline
\end{tabular}

Out of 60 patients, 3 patients had lymphocytes plus mesothelial cells, 42 patients had predominantly lymphocytes and 15 patients had predominantly neutrophils. 
Table 7. Distribution of pleural protein

\begin{tabular}{l|l}
\hline Pleural protein $($ gram/dl) & Number $(\mathbf{n}=60)$ \\
\hline $1-2$ & 6 \\
\hline $2-4$ & 16 \\
\hline $4-6$ & 34 \\
\hline$>6$ & 4 \\
\hline Total & 60 \\
\hline
\end{tabular}

The above table shows the values of pleural protein. 6 patients had pleural protein values ranging from 1-2 gram/dl, 16 patients of pleural protein ranging from 2-4 gram/dl, 34 patients ranging from 4-6 gram/dl and 4 patients had protein levels above 6 gram/dl.

Table 8. Distribution of pleural cholesterol

\begin{tabular}{l|l}
\hline Pleural cholesterol & N \\
\hline$<45 \mathrm{mg} / \mathrm{dl}$ & 15 \\
\hline$>45 \mathrm{mg} / \mathrm{dl}$ & 45 \\
\hline Total & 60 \\
\hline
\end{tabular}

15 patients had pleural cholesterol levels less than 45 $\mathrm{mg} / \mathrm{dl}$ and 45 patients had cholesterol level above 45 $\mathrm{mg} / \mathrm{dl}$.

Table 9. Biochemical analysis of pleural effusion

\begin{tabular}{l|l|l|l}
\hline $\begin{array}{l}\text { Parame- } \\
\text { ters } \mathbf{( g / d )}\end{array}$ & Exudates & $\begin{array}{l}\text { Transu- } \\
\text { date }\end{array}$ & P VALUE \\
\hline & $\begin{array}{l}\text { Mean } \pm \\
\text { SD }\end{array}$ & Mean \pm SD & \\
\hline
\end{tabular}

Lights criteria (transudate $=14$ exudate $=46$ )

\begin{tabular}{l|l|l|l}
\hline $\begin{array}{l}\text { Serum } \\
\text { protein(g/ } \\
\mathrm{dl})\end{array}$ & $5.7 \pm 1$ & $6.1 \pm 1.1$ & 0.215 \\
\hline $\begin{array}{l}\text { Pleural } \\
\text { protein(g/ } \\
\mathrm{dl})\end{array}$ & $4.7 \pm 1$ & $2.4 \pm 0.9$ & $<0.001^{*}$ \\
\hline $\begin{array}{l}\text { Pleural } \\
\text { sugar(mg/ } \\
\mathrm{dl})\end{array}$ & $68.2 \pm 40.1$ & $126.7 \pm 76$ & $<0.001^{*}$ \\
\hline $\begin{array}{l}\text { Pleural } \\
\text { fluid pro- } \\
\text { tein:Serum } \\
\text { protein }\end{array}$ & $0.8 \pm 0.2$ & $0.3 \pm 0.1$ & $<0.001^{*}$ \\
\hline
\end{tabular}

Pleural cholesterol criteria(transudate $=15$ exudate $=45$ )

\begin{tabular}{l|l|l|l}
\hline $\begin{array}{l}\text { Pleural } \\
\text { cholesterol } \\
(\mathrm{mg} / \mathrm{dl})\end{array}$ & $78.2 \pm 23.7$ & $21.9 \pm 9.2$ & $<0.001 *$ \\
\hline
\end{tabular}

Note: * significant at $5 \%$ level of significance $(\mathrm{p}<0.05)$. The $\mathrm{p}$ value of serum protein is 0.215 ,

According to Lights Criteria, the mean serum protein is $5.7 \pm 1.0$ in exudates and $6.1 \pm 1.1$ has $p$ value of 0.215 . The mean pleural protein is $4.7 \pm 1.0$ in exudates and $2.4 \pm 0.9$ has $p$ value of 0.001 . The mean pleural sugar is $68.2 \pm 40.1$ in exudates and $126.7 \pm 75.9$ has $p$ value of 0.001 . The mean pleural protein: serum protein is
$0.8 \pm 0.2$ in exudates and $0.3 \pm 0.1$ has $p$ value of 0.001 According to pleural cholesterol criteria, the mean pleural cholesterol is $78.2 \pm 23.7$ in exudates and $21.9 \pm 9.2$ and has $p$ value of 0.001 which is statistically significant.

pleural protein is $<0.001$, pleural sugar is $<0.001$, pleural cholesterol is $<0.001$, pleural fluid protein: serum protein is $<0.001$. $\mathrm{P}$ value of $<0.001$ is statistically significant.

Table 10. Distribution of exudates and transudate according to lights criteria and pleural fluid cholesterol criteria $^{3}$

\begin{tabular}{l|l|l}
\hline Based on lights criteria & N & \% \\
\hline Exudate & 46 & 76.7 \\
\hline Transudate & 14 & 23.3 \\
\hline Based on cholesterol criteria & \multicolumn{2}{|l}{} \\
\hline Exudate & 45 & 75 \\
\hline Transudate & 15 & 25 \\
\hline
\end{tabular}

Based on Lights criteria, out of 60 patients 46 were exudates $(76.7 \%)$ and 14 were transudates $(23.3 \%)$.Based on pleural cholesterol level criteria, out of 60 patients 45 $(75 \%)$ were exudates and $15(25 \%)$ were transudates.

Table 11. Result of sputum AFB

\begin{tabular}{l|l|l|l}
\hline \multirow{2}{*}{ Sputum AFB } & \multicolumn{2}{|l|}{ TOTAL } & \multirow{2}{*}{ P VALUE } \\
\cline { 2 - 3 } & $\mathrm{N}$ & $\%$ & \\
\hline Negative & 28 & 46.7 & \multirow{2}{*}{0.232} \\
\hline Positive & 32 & 53.3 & \\
\hline Total & 60 & 100.0 & \\
\hline
\end{tabular}

In the study group of 60 patients, sputum AFB was positive in $32(53.3 \%)$ patients and $28(53.3 \%)$ patients had sputum AFB was negative.

Table 12. USG abdomen examination in pleural effusion

\begin{tabular}{l|l|l|l}
\hline \multirow{2}{*}{ USG } & \multicolumn{2}{|l|}{ Total } & \multirow{2}{*}{ p value } \\
\cline { 2 - 3 } & $\mathrm{N}$ & $\%$ & \\
\hline $\begin{array}{l}\text { Cirrhosis with por- } \\
\text { tal hypertension }\end{array}$ & 7 & 11.7 & \\
\hline Mild hepatomegaly & 1 & 1.7 & \\
\hline Minimal ascites & 1 & 1.7 & \multirow{2}{*}{0.182} \\
\hline Normal & 39 & 65.0 & \\
\hline Not done & 12 & 20.0 & \\
\hline Total & 60 & 100.0 & \\
\hline
\end{tabular}

In the study group of 60 patients, cirrhosis was present in 7 patients, hepatomegaly in 1 patient, ascites in 1 patient, and normal in 39 patients. 
Table 13. Comparison of exudative and transudative pleural effusion according to pleural fluid cholesterol criteria and lights criteria

\begin{tabular}{l|l|l|l}
\hline & $\begin{array}{l}\text { According to } \\
\text { pleural fluid } \\
\text { cholesterol } \\
\text { criteria }\end{array}$ & $\begin{array}{l}\text { According } \\
\text { to lights } \\
\text { criteria }\end{array}$ & P value \\
\hline & $\mathrm{N}(\%)$ & $\mathrm{N}(\%)$ & \\
\hline Exudate & $45(75)$ & $46(76.6)$ & \multirow{2}{*}{$<0.001^{*}$} \\
\cline { 1 - 2 } $\begin{array}{l}\text { Transu- } \\
\text { date }\end{array}$ & $15(25)$ & $14(23.3)$ & \\
\hline Total & 60 & 60 & \\
\hline
\end{tabular}

Note: * significant at $5 \%$ level of significance $(\mathrm{p}<0.05)$

Based on lights criteria 46 patients were exudate and 14 patients were transudative pleural effusion, based on cholesterol criteria 45 patients were exudative and 15 were transudative pleural effusion.

The $\mathrm{p}$ value is $<0.001$ which is statistically significant.

Table 14. Sensitivity analysis of pleural cholesterol criteria

\begin{tabular}{l|l}
\hline TP (true positive) & $\mathbf{4 5}$ \\
\hline FN (false negative) & 1 \\
\hline FP (false positive) & 0 \\
\hline TN (true negative) & 14 \\
\hline Sensitivity & $97.8 \%$ \\
\hline Specificity & $100.0 \%$ \\
\hline PPV(positive predictive value) & $100.0 \%$ \\
\hline NPV(negative predictive value) & $93.3 \%$ \\
\hline Accuracy & $98.3 \%$ \\
\hline
\end{tabular}

\section{DISCUSSION}

A total of 60 patients were taken up for this study. Out of 60,46 were exudates and 14 were transudates. Among 46 exudates, 40 were tubercular effusions, 5 patients were synpneumonic effusion and 1 patient with malignant effusion.

Among 14 transudative, 7 patients were congestive cardiac failure, 7 patients were cirrhosis.

Age and sex: The age of the patient in this study ranged from 18 years to 75 years. 1 patient was 18 years, 9 patients were between 21-30 years, 15 patients were between 31-40 years, 15 patients were between 41-50 years, 13 patients were between 51-60 years and 7 patients were above 60 years. Out of 60 patients, males were 38 and females were 22 .

$\mathrm{Hamm}^{4}$ first used pleural cholesterol as a parameter. In his study of 150 patients he found excellent results (Sensitivity 93\%, Specificity 100\%, Accuracy 96\%). Following Hamm's [4], Valdes [5] aimed to validate this parameter. In his study of 74 patients pleural cholesterol had good results as shown in the above table. Similar results were obtained from studies by Ram [6] in 100 patients and B N Mohaptra [7] in his study of 132 patients. The studies of Burgess [8] and Remero [9] of 124 patients, results were in favour of lights criteria but they had less sensitivity, specificity and accuracy. As a result the present study of 60 patients which contains Pleural Cholesterol criteria has more sensitivity, specificity and accuracy when compared to other studies done by Burgess and Remero which contains Lights criteria.

The study shows that pleural fluid cholesterol criteria (cholesterol $>45 \mathrm{mg} / \mathrm{dl}$ - exudate and cholesterol $<45$ $\mathrm{mg} / \mathrm{dl}$ - transudate) constitute a useful tool for the separation of pleural effusions.

\section{CONCLUSION}

The pleural fluid cholesterol criteria were found to be the most efficient criteria. Since this parameter involves the measurement of only pleural fluid values of cholesterol, it has following advantages: Economically, it reduces number of biochemical tests, Simpler, as there is no need to take simultaneous blood sample at the time of thoracocentesis.

It is concluded that the determination of pleural fluid cholesterol criteria can be included in routine analysis of pleural fluid samples in place of presently used Lights Criteria.

Acknowledgements: I would also like to express my sincere thanks to our vice chancellor Dr. M S Biradar, for his useful advice and kind support. I would like to thank the god who gave me the energy, skill and upon me.

\section{REFERENCES}

1. Donald.DD, Ralph AD, Eleuterio Ferrannini. Pleural effusion- A Diagnostic dilemma. JAMA 1 976;236(2):183-6.

2. Hampson E, Donald Chisholm, Xavier Pi-Sunyer. Complications of Pleural effusion. Needle biopsy of parietal pleura in the diagnosis of pleural effusion .Q.J.MED 1961;34: 106-12.

3. Light RW. Approach to Management of Pleural effusion. ANN 1NT MED 1966; 64: 341-51.

4. Hamm H, Jordan DT, Reubin Andres. Cholesterol in pleural effusion- A diagnostic aid. CHEST 1987;92: 296-301.

5. Louis Valdes, Flegal KM, Troiano RP. Cholesterol- A useful parameter for distinguishing between pleural exudates and transudates.

6. Ram KN, Chandalia M, Abate N, Garg A. Diagnostic value of Cholesterol as a parameter in classifying pleural effusions as transudates and exudates. JAPI 1995; 43(11):748-50.

7. Mohapatra BN, Sastry NG, Mohan V. Significance of Pleural fluid Cholesterol in differentiating transudates and exudates. JAPI. 1995;116119.

8. Lesley JB. Frans JM, FransTaljaarcl JJ. Comparative analysis of the biochemical parameters used to distinguish between pleural exudates and transudates. CHEST 1995; 107: 1604-9.

9. Romero Orts David. Hemandez Luis. Evaluation of different criteria for the separation of pleural transudates and exudates. CHEST 1993;104:399407. 